\title{
Vitamin D receptor (VDR) Taql polymorphism, vitamin D and bone mineral density in patients with inflammatory bowel diseases
} \author{
Michał Michalak ${ }^{4, C}$, Agnieszka Dobrowolska ${ }^{1, E, F}$, Ryszard Słomski, ${ }^{3,2, E, F}$ \\ ${ }^{1}$ Department of Gastroenterology, Human Nutrition and Internal Medicine, Poznan University of Medical Sciences, Poland \\ 2 Institute of Human Genetics, Polish Academy of Sciences, Poznań, Poland \\ ${ }^{3}$ Department of Biochemistry and Biotechnology, Poznan University of Life Sciences, Poland \\ ${ }^{4}$ Department of Computer Sciences and Statistics, Poznan University of Medical Sciences, Poland \\ A - research concept and design; $B$ - collection and/or assembly of data; $C$ - data analysis and interpretation; \\ $D$ - writing the article; $E$ - critical revision of the article; $F$ - final approval of the article
}

Aleksandra Szymczak-Tomczak ${ }^{1, A, B, D}$, Iwona Krela-Kaźmierczak ${ }^{1, A, B, D}$, Marta Kaczmarek-Ryś2,B, ${ }^{2}$, Szymon Hryhorowicz, ${ }^{2, B, C}$, Kamila Stawczyk-Eder ${ }^{1, B, D}$, Marlena Szalata ${ }^{3, B}$, Marzena Skrzypczak-Zielińska ${ }^{3, C}$, Liliana Łykowska-Szuber ${ }^{1, B}$, Piotr Eder ${ }^{1, E, F}$,

Address for correspondence

Aleksandra Szymczak-Tomczak

E-mail: aleksandra.szymczak@02.pl

\section{Funding sources}

This study was financed by the Polish Ministry of Science and Higher Education. Project No. 402481737.

\section{Conflict of interest}

The Author(s) represents that the conflict of interest applies to the conflict-of-interest statement: IKK received travel grants from Alvogen, Abbvie and Astellas; PE received lecture fees from Abbvie Poland and travel grants from Astellas, Abbvie Poland and Ferring; $A D$ received travel grants from Alvogen, Abbvie and Astellas and lecture fees from Abbvie Poland and Alvogen; LLS received travel grants from Alvogen, Astellas and Abbvie Poland; AST received travel grant from Abbvie Poland; KSE received travel grants from Alvogen. MKR, MSZ, MS, SzH, MM and RD have nothing to disclose.

\section{Acknowledgements}

In memory of the late Prof. Wanda Horst-Sikorska who supported us with her ideas, knowledge and kindness, and the late Prof. Krzysztof Linke who also supported us with his ideas, knowledge and kindness.

Received on August 11, 2018

Reviewed on September 30, 2018

Accepted on October 8, 2018

Published online on March 28, 2019

DOI

10.17219/acem/97376

Copyright

Copyright by Author(s)

This is an article distributed under the terms of the Creative Commons Attribution Non-Commercial License (http://creativecommons.org/licenses/by-nc-nd/4.0/)

\begin{abstract}
Background. A common feature in the etiology of inflammatory bowel disease (IBD) and osteoporosis is a complex genetic background. Moreover, it has been shown that some of the susceptibility loci overlap for both diseases. One of the genes that may be involved in the pathogenesis of IBD as well as decreased bone mass is the vitamin D receptor (VDR) gene.
\end{abstract}

Objectives. The aim of this study was to investigate the association of the Taql polymorphism (rs731236, c.1056T >C) in the VDR gene with serum vitamin D concentration and bone mineral density (BMD) in patients with IBD.

Material and methods. A total of 172 IBD patients (85 with Crohn's disease (CD) and 87 with ulcerative colitis (UC)) and 39 healthy controls were enrolled in the study. Polymorphism was determined with polymerase chain reaction (PCR) and restriction fragment length polymorphism (RFLP). Bone mineral density was measured at the lumbar spine (L2-L4) and the femoral neck (FN) using dual-energy $x$-ray absorptiometry (DEXA). Serum concentrations of 25-hydroxyvitamin D were determined using electrochemiluminescence binding assay (ECLIA).

Results. Our studies revealed that serum vitamin D concentration in IBD patients was not lowered in comparison with healthy controls. Patients with CD presented more advanced osteopenia and osteoporosis. Individuals with UC carrying the Taql tt genotype of VDR gene showed significantly higher FN BMD than carriers of TT and Tt genotypes ( $p=0.02)$. Moreover, tt genotype was present with higher frequency in UC patients than in controls and CD patients (23\% vs 7.7\% and 16.5\%, respectively).

Conclusions. The tt genotype may have a protective effect on BMD in UC patients.

Key words: vitamin D, bone mineral density, inflammatory bowel diseases, vitamin D receptor gene polymorphism

Cite as

Szymczak-Tomczak A, Krela-Kaźmierczak I, Kaczmarek-Ryś M. Vitamin D receptor (VDR) Taql polymorphism, vitamin $D$ and bone mineral density in patients with inflammatory bowel diseases. Adv Clin Exp Med. 2019;28(7):955-960. doi:10.17219/acem/97376 


\section{Introduction}

Inflammatory bowel disease (IBD) is an idiopathic disease caused by uncontrolled mucosal immunity of the gastrointestinal tract, but its pathogenesis is not fully understood. ${ }^{1}$ It has been suggested that it originates from a combination of environmental (intestinal microbiota), immunological (impaired regulation of T-helper lymphocytes, Th) and complex genetic factors. ${ }^{2,3}$ Inflammatory bowel disease does not concern only the gastrointestinal system and should be treated as a systemic disease with a number of manifestations outside the digestive tract, among which osteopenia and osteoporosis are the most common. ${ }^{4}$ Even $22-77 \%$ of patients with IBD suffer from osteopenia and $17-41 \%$ of suffer from osteoporosis. ${ }^{5-7}$ Lean body structure, age over 65, low-protein and low-calcium diet, cigarette smoking, alcohol drinking, vitamin D deficiency, the use of some pharmaceutical drugs, and compound genetic factors are osteoporosis risk factors. Osteoporosis susceptibility genes encode proteins that control bone formation and the maintenance of the normal bone tissue structure. They belong to different families of biological factors such as cytokines, growth factors, matrix components, and calciotropic hormone receptors. ${ }^{8,9}$ To date, almost 200 susceptibility loci have been identified for IBD. Some of them are characteristic for Crohn's disease (CD) or ulcerative colitis (UC) and some of them overlap. Moreover, susceptibility loci may be also common for IBD and osteoporosis. ${ }^{10,11}$ One of such genes is the vitamin $\mathrm{D}$ receptor $(V D R)$ gene, encoding the vitamin $\mathrm{D}\left(1,25(\mathrm{OH})_{2} \mathrm{D}_{3}\right)$ receptor belonging to a family of nuclear receptors and acting as a ligand-activated transcriptional factor. Activation of the $V D R$ through direct interaction with $1,25(\mathrm{OH})_{2} \mathrm{D}_{3}$ prompts the rapid binding of the receptor to regulatory regions of target genes, where it causes directed changes in transcription. This receptor plays a central role in the biological actions of vitamin $D$; moreover, $V D R$ regulates the expression of numerous genes involved in calcium/phosphate homeostasis, cellular proliferation and differentiation, and immune response. ${ }^{12} \mathrm{Vi}-$ tamin $\mathrm{D}$ is a prohormone that is metabolized to its active form, 1,25-dihydroxycalciferol (calcitriol), having both calcemic and non-calcemic (pleiotropic) effects. The most important calcemic effects include inducing calcium and phosphate absorption in the digestive system, increasing renal calcium reabsorption and inducing bone turnover. ${ }^{9}$

According to the latest data, patients with IBD suffer from vitamin D deficiency. ${ }^{13}$ Decreased exposition to sunlight, ${ }^{14}$ inappropriate diet, inflammatory changes in the bowel mucosa, and consequences of the digestive tract resection are considered the main reason for this problem. ${ }^{15-17}$ This leads to osteomalacia (defective bone mineralization with the maintenance of the normal bone mass) and osteoporosis (a decrease of the properly mineralized bone mass). Moreover, vitamin D may have an important effect on the course of the disease through modulation of the inflammation mechanisms.
It has been shown that polymorphisms in the VDR gene are related with changes in bone mineral density (BMD). Furthermore, earlier reports showed that the VDR alterations might increase the risk of IBD in Caucasians and Asians. ${ }^{18,19}$ The mechanism of this phenomenon is difficult to explain. The 3' region of the VDR gene is involved in the regulation of gene expression, which affects the stability of mRNA. In turn, it may lead to a decreased concentration of mRNA resulting in decreased vitamin $\mathrm{D}$ levels and a reduction in its inhibitory effects on interleukin 12 (IL-12). Changes in the immune system result in increased Th1-dependent reaction, which may explain the susceptibility to CD. What is also significant is the linkage disequilibrium (LD); the $V D R$ gene polymorphisms may be in strong linkage with another, unknown sequence variant, which has a causative effect. ${ }^{20}$ Considering the above premises, we decided to deal with this issue. The aim of this study was to analyze the association between the TaqI polymorphism in the $V D R$ gene and serum vitamin D concentration as well as BMD in patients with inflammatory bowel disease.

\section{Materials and methods}

\section{Patients and clinical data}

The study group included 172 IBD patients from the Clinic of Gastroenterology, Human Nutrition and Internal Diseases of the Poznan University of Medical Sciences (Poland), comprising of $85 \mathrm{CD}$ and $87 \mathrm{UC}$ patients. The control group consisted of 39 healthy volunteers without IBD or any bone disorders. Peripheral blood and clinical data were collected from all study subjects. The clinical examination included measurements of BMD of the lumbar spine (L2-L4 levels) and of the femoral neck (FN). The data on weight, height and age at densitometry was also collected. Patients included into the study were not taking any vitamin D supplements. Densitometry measurements were conducted with dual energy X-ray absorptiometry (DEXA) using the DPX-Plus device (Lunar, GE Healthcare, Chicago, USA). Serum concentrations of 25-hydroxyvitamin D $(25(\mathrm{OH}) \mathrm{D})$, as markers of vitamin D sufficiency in the organism, were determined using an electro-chemiluminescence binding assay and a Cobas e601 analyzer (Roche, Basel, Switzerland). The functional sensitivity of these assays is $4.01 \mathrm{ng} / \mathrm{mL}$ (coefficient of variation: $18.5 \%)$. All patients gave their written consent to genetic testing scheduled within this study. The study was approved by the local Ethical Committee of the Poznan University of Medical Sciences (approval No. 92/09).

\section{DNA extraction and VDR polymorphism analysis}

DNA was isolated from peripheral blood leukocytes using guanidine isothiocyanate and phenol-chloroform 
as described elsewhere. ${ }^{21}$ DNA fragments including the polymorphic sites of the $V D R$ gene were amplified using polymerase chain reaction (PCR). Each amplification reaction contained $100 \mathrm{ng}$ of genomic DNA, $0.25 \mathrm{mM}$ dNTP, 7.5 pmol of each primer, and 0.5 unit of the Taq polymerase (Sigma Aldrich, Saint Louis, USA) in $20 \mu \mathrm{L}$ total volume. The reaction was conducted in 35 cycles of the following steps: initial denaturation at $94^{\circ} \mathrm{C}$ for $4 \mathrm{~min}$; denaturation at $94^{\circ} \mathrm{C}$ for $40 \mathrm{~s}$; primer annealing at $64^{\circ} \mathrm{C}$ for $40 \mathrm{~s}$; elongation at $72^{\circ} \mathrm{C}$ for $100 \mathrm{~s}$; and final incubation at $72^{\circ} \mathrm{C}$ for $180 \mathrm{~s}$. PCR primers: forward CAG AGC ATG GAC AGG GAG CAA and reverse GCA ACT CCT CAT GGC TGA GGT CTC were used. ${ }^{22}$ The amplification products were subsequently hydrolyzed using TaqI restriction enzyme (New England Biolabs, Ipswich, USA) at $65^{\circ} \mathrm{C}$ for $2 \mathrm{~h}$. Digestion products were separated in an agarose gel (1.5\%) with ethidium bromide. Alleles of TaqI polymorphism (allele T(c.1056C): $494+251$ bp and allele t (c.1056T): $293+251+201$ bp) were identified in comparison to the control samples determined with Sanger sequencing.

\section{Statistical analysis}

We conducted an analysis of the distribution of genotype concordance with the Hardy-Weinberg equilibrium. First, the normality of the distribution and the homogeneity of variable variances were conducted in the studied groups using the Shapiro-Wilk t test and Levene's test, respectively. In the event of non-concordance with 2 or at least 1 condition, the non-parametric Kruskal-Wallis $\mathrm{H}$ test was used to compare the groups. In the event of a statistically significant heterogeneity between the groups, multiple comparisons were conducted using the Dunn's test in order to evaluate an association between qualitative variables (the 3 study groups vs groups carrying different $V D R$ genotypes). All analyses were conducted using STATISTICA v. 10.0 software (StatSoft Inc., Tulsa, USA) and the calculator on the http://ihg.gsf.de/cgi-bin/hw/hwa1.pl website. P-values below 0.05 were considered as indicative of a statistical significance.

\section{Results}

The basic characteristics of the study subjects have been summarized in Table 1. The comparison of investigated groups has shown differences in BMI, which occurred significantly reduced in IBD patients than in controls. Moreover, CD patients presented lower BMI than UC patients. We observed decreased BMD of lumbar spine and FN in patients with CD and UC. Individuals with CD presented more advanced osteopenia and osteoporosis than patients with UC. However, we did not find statistically significant differences in vitamin D concentration between studied groups (Table 1). The genotypes distribution in examined groups was concordant with the Hardy-Weinberg equilibrium.
Table 1. Basic characteristics and clinical parameters of the study subjects.

\begin{tabular}{|c|c|c|c|c|}
\hline $\begin{array}{c}\text { Parameter } \\
\text { mean }\end{array}$ & $\begin{array}{c}\text { CD patients } \\
n=85\end{array}$ & $\begin{array}{l}\text { UC patients } \\
\qquad n=87\end{array}$ & $\begin{array}{c}\text { Controls } \\
n=39\end{array}$ & $p$-value \\
\hline $\begin{array}{l}\text { Age } \\
\text { [years] }\end{array}$ & $\begin{array}{c}35.24 \\
\text { (SD 12.12) }\end{array}$ & $\begin{array}{c}39.40 \\
\text { (SD 14.43) }\end{array}$ & $\begin{array}{c}30.74 \\
\text { (SD 8.6) }\end{array}$ & ${ }^{c} p=0.040$ \\
\hline $\begin{array}{l}\text { Weight } \\
{[\mathrm{kg}]}\end{array}$ & $\begin{array}{c}63.20 \\
\text { (SD 13.86) }\end{array}$ & $\begin{array}{c}68.63 \\
(S D 14.92)\end{array}$ & $\begin{array}{c}73.62 \\
\text { (SD 13.65) }\end{array}$ & ${ }^{b} p<0.001$ \\
\hline $\begin{array}{l}\text { Height } \\
{[\mathrm{cm}]}\end{array}$ & $\begin{array}{c}171.39 \\
(S D 10.30)\end{array}$ & $\begin{array}{c}170.80 \\
\text { (SD 9.74) }\end{array}$ & $\begin{array}{c}172.69 \\
\text { (SD 9.35) }\end{array}$ & $p=0.70$ \\
\hline $\begin{array}{l}\text { BMI } \\
{\left[\mathrm{kg} / \mathrm{m}^{2}\right]}\end{array}$ & $\begin{array}{c}21.36 \\
\text { (SD 3.62) }\end{array}$ & $\begin{array}{c}23.43 \\
(\mathrm{SD} 4.32)\end{array}$ & $\begin{array}{c}24.57 \\
\text { (SD 3.45) }\end{array}$ & $\begin{array}{l}{ }^{a} p<0.001 \\
{ }^{b} p<0.001\end{array}$ \\
\hline $\begin{array}{l}\text { L2- L4 BMD } \\
{\left[\mathrm{g} / \mathrm{cm}^{2}\right]}\end{array}$ & $\begin{array}{c}1.12 \\
\text { (SD } 0.18)\end{array}$ & $\begin{array}{c}1.16 \\
\text { (SD } 0.14)\end{array}$ & $\begin{array}{c}1.22 \\
(\mathrm{SD} 0.08)\end{array}$ & $\begin{array}{l}{ }^{b} p<0.001 \\
{ }^{c} p=0.01\end{array}$ \\
\hline L2-L4 T-score & $\begin{array}{c}-0.82 \\
(\mathrm{SD} 1.45)\end{array}$ & $\begin{array}{c}-0.46 \\
(S D 1.15)\end{array}$ & $\begin{array}{c}0.09 \\
(\mathrm{SD} 0.70)\end{array}$ & $\begin{array}{l}{ }^{b} p<0.001 \\
{ }^{c} p=0.007\end{array}$ \\
\hline $\begin{array}{l}\text { L2-L4 } \\
\text { Z-score }\end{array}$ & $\begin{array}{c}-0.41 \\
(S D 1.32)\end{array}$ & $\begin{array}{c}-0.18 \\
\text { (SD 1.19) }\end{array}$ & $\begin{array}{c}0.09 \\
\text { (SD 0.66) }\end{array}$ & ${ }^{b} p=0.03$ \\
\hline $\begin{array}{l}\text { FN BMD } \\
{\left[\mathrm{g} / \mathrm{cm}^{2}\right]}\end{array}$ & $\begin{array}{c}0.95 \\
(\text { SD } 0.18)\end{array}$ & $\begin{array}{c}0.98 \\
(\mathrm{SD} 0.15)\end{array}$ & $\begin{array}{c}1.07 \\
\text { (SD 0.16) }\end{array}$ & $\begin{array}{l}{ }^{b} p<0.001 \\
{ }^{c} p=0.003\end{array}$ \\
\hline FN T-score & $\begin{array}{c}-0.65 \\
\text { (SD 1.28) }\end{array}$ & $\begin{array}{c}-0.31 \\
(S D 1.14)\end{array}$ & $\begin{array}{c}0.41 \\
\text { (SD 1.03) }\end{array}$ & $\begin{array}{l}{ }^{b} p<0.001 \\
{ }^{c} p=0.001\end{array}$ \\
\hline FN Z-score & $\begin{array}{c}-0.27 \\
(\mathrm{SD} 1.08)\end{array}$ & $\begin{array}{c}0.06 \\
\text { (SD 1.04) }\end{array}$ & $\begin{array}{c}0.38 \\
\text { (SD 0.99) }\end{array}$ & ${ }^{b} p=0.002$ \\
\hline $\begin{array}{l}25-O H D \\
{[\mathrm{ng} / \mathrm{mL}]}\end{array}$ & $\begin{array}{c}21.43 \\
\text { (SD 12.32) }\end{array}$ & $\begin{array}{c}22.06 \\
\text { (SD 9.27) }\end{array}$ & $\begin{array}{c}21.56 \\
\text { (SD 9.11) }\end{array}$ & $p=0.77$ \\
\hline
\end{tabular}

BMD - bone mineral density; CD - Crohn's disease; FN - femoral neck; ns - non-significant; SD - standard deviation; UC - ulcerative colitis. All results are presented as means with standard deviations (SD); ${ }^{a} \mathrm{CD}$ vs UC; ${ }^{b} \mathrm{CD}$ vs controls; ${ }^{c} U \mathrm{C}$ vs controls.

We observed that tt genotype was present with higher frequency in UC patients than in controls and CD patients (23\% vs $7.7 \%$ and $16.5 \%$, respectively). Comparing the whole group of IBD patients with controls we pointed out that tt genotype was almost 3 times more frequent than TT+Tt genotypes $(\mathrm{OR}=2.96)$, but this observation was borderline significant $(\mathrm{p}=0.07)$. The same analysis performed in UC group revealed that in these patients $t \mathrm{t}$ homozygotes occurred even more frequently $(\mathrm{OR}=3.58$, 95\% CI $=1.00-12.87, \mathrm{p}$-value $=0.04)($ Table 2$)$.

In the next step, we carried out the analysis of bone mass parameters and serum vitamin $D$ levels in correlation with TaqI genotypes of VDR gene. Patients with CD did not significantly differ in lumbar spine (L2-L4) and FN BMD, T-score, Z-score, nor in $25(\mathrm{OH}) \mathrm{D}$ serum concentration ( $\mathrm{p}>0.05$ for all comparisons); however, we have noticed slightly higher bone mass parameters values in tt genotype carriers, while in TT homozygotes they were the most decreased. Considering UC patients, lumbar spine values of BMD, T-score and Z-score as well as FN, have emerged higher in tt homozygotes even more clearly; the differences between FN BMD values in different genotypes carriers were statistically significant (overall $\mathrm{p}=0.02$, post hoc $\mathrm{p}$ : $[\mathrm{tt}]$ vs $[\mathrm{Tt}]=0.02)$ (Table 3 ). In controls, we made the same observations, although in post hoc tests they remained borderline significant or insignificant. 
Table 2. Alleles and genotypes frequency in VDRTaql (rs731236, c.1056T>C) loci

\begin{tabular}{|c|c|c|c|c|c|}
\hline \multirow{2}{*}{ Group } & \multirow{2}{*}{$\begin{array}{c}\text { Genotype frequencies (\%) } \\
\text { TT }\end{array}$} & \multicolumn{4}{|c|}{ Allele frequencies (\%) } \\
\hline & & Tt & $\mathrm{tt}$ & $\mathrm{T}$ & $\mathrm{t}$ \\
\hline IBD (all patients), $\mathrm{n}=172$ & $59(34.3)$ & $79(45.9)$ & $34(19.8)$ & $197(57.3)$ & $147(42.7)$ \\
\hline UC patients, $n=87$ & $31(35.6)$ & $36(41.4)$ & $20(23.0)$ & $98(56.3)$ & $76(43.7)$ \\
\hline CD patients, $n=85$ & $28(32.9)$ & $43(50.6)$ & $14(16.5)$ & $99(58.2)$ & $71(41.8)$ \\
\hline Controls, $n=39$ & $13(33.3)$ & $23(59.0)$ & $3(7.7)$ & $49(62.8)$ & $29(37.2)$ \\
\hline \multirow{2}{*}{ Group } & \multicolumn{5}{|c|}{ Comparisons of allelic and genotypic frequencies between groups under study } \\
\hline & {$[t t]$ vs $[T T+T t]$} & {$[\mathrm{TT}]$ vs $[\mathrm{Tt}+\mathrm{tt}]$} & {$[\mathrm{tt}]$ vs $[\mathrm{TT}]$} & {$[\mathrm{T}]$ vs $[\mathrm{t}]$} & {$[\mathrm{t}]$ vs $[\mathrm{T}]$} \\
\hline \multirow{2}{*}{$\begin{array}{l}\text { IBD vs controls } \\
\text { OR, } 95 \% \mathrm{Cl} \\
\text { p-value }\end{array}$} & \multirow{2}{*}{$\begin{array}{c}\mathrm{OR}=2.96 \\
(0.86-10.18) \\
p=0.07\end{array}$} & \multirow{2}{*}{$\begin{array}{c}\mathrm{OR}=1.04 \\
(0.50-2.18) \\
p=0.91\end{array}$} & \multirow{2}{*}{$\begin{array}{c}O R=2.45 \\
(0.66-9.39) \\
P=0.17\end{array}$} & $\begin{array}{l}\mathrm{OR}=0.79 \\
(0.48-1.32)\end{array}$ & $\begin{array}{l}\mathrm{OR}=1.26 \\
(0.76-2.09)\end{array}$ \\
\hline & & & & $p=0.37$ & \\
\hline \multirow{2}{*}{$\begin{array}{l}\text { UC vs controls OR, } 95 \% \mathrm{Cl} \\
\text { p-value }\end{array}$} & \multirow{2}{*}{$\begin{array}{c}\text { OR }=3.58 \\
(1.00-12.87) \\
p=0.04\end{array}$} & \multirow{2}{*}{$\begin{array}{c}\mathrm{OR}=1.11 \\
(0.50-2.46) \\
p=0.80\end{array}$} & \multirow{2}{*}{$\begin{array}{c}O R=2.80 \\
(0.71-11.06) \\
p=0.13\end{array}$} & $\begin{array}{l}\mathrm{OR}=0.76 \\
(0.44-1.32)\end{array}$ & $\begin{array}{l}\mathrm{OR}=1.31 \\
(0.76-2.27)\end{array}$ \\
\hline & & & & $p=0.33$ & \\
\hline \multirow{2}{*}{$\begin{array}{l}\text { CD vs controls } \\
\text { OR, } 95 \% \mathrm{Cl} \\
\text { p-value }\end{array}$} & \multirow{2}{*}{$\begin{array}{c}O R=2.37 \\
(0.64-8.77) \\
p=0.19\end{array}$} & \multirow{2}{*}{$\begin{array}{c}\mathrm{OR}=0.98 \\
(0.44-2.20) \\
p=0.97\end{array}$} & \multirow{2}{*}{$\begin{array}{c}O R=2.17 \\
(0.53-8.87) \\
p=0.28\end{array}$} & $\begin{array}{l}\mathrm{OR}=0.83 \\
(0.48-1.43)\end{array}$ & $\begin{array}{l}\mathrm{OR}=1.21 \\
(0.70-2.10)\end{array}$ \\
\hline & & & & $p=0.49$ & \\
\hline \multirow{2}{*}{$\begin{array}{l}\text { CD vs UC } \\
\text { OR, } 95 \% \mathrm{Cl} \\
p \text {-value }\end{array}$} & \multirow{2}{*}{$\begin{array}{c}\mathrm{OR}=0.66 \\
(0.31-1.41) \\
p=0.28\end{array}$} & \multirow{2}{*}{$\begin{array}{c}\mathrm{OR}=0.89 \\
(0.47-1.67) \\
p=0.71\end{array}$} & \multirow{2}{*}{$\begin{array}{c}\mathrm{OR}=0.78 \\
(0.33-1.82) \\
\mathrm{p}=0.56\end{array}$} & $\begin{array}{l}\mathrm{OR}=1.08 \\
(0.71-1.66)\end{array}$ & $\begin{array}{l}\mathrm{OR}=0.93 \\
(0.60-1.42)\end{array}$ \\
\hline & & & & $p=0.72$ & \\
\hline
\end{tabular}

In bold were marked statistically significant $(\mathrm{p}<0.05)$ and borderline results. $\mathrm{Cl}$ - confidence intervals; OR - odds ratio.

\section{Discussion}

In this study, we analyzed $V D R$ gene TaqI polymorphic variants and their relation to BMD parameters and serum vitamin $D$ levels in a particular group of patients with IBD. The $V D R$ gene was one of the first genes studied with regard to its possible role in the development of osteoporosis. ${ }^{23-25}$ Vitamin D binds to a specific steroid receptor that has a transcription factor activity. The formation of vitamin D steroid receptor complex results in the activation or silencing of target gene expression. This leads to synthesis regulation of proteins that actively participate in bone metabolism and calcium homeostasis. ${ }^{26}$ Alterations in the $V D R$ gene may result in alterations of the structure, function and/or activity of the VDR protein, i.e., affect the transcription factor participating in the signal transduction from vitamin D to genes that are under its control. Studies on $V D R$ gene polymorphisms showed divergent results in the analyzed groups of patients and populations. ${ }^{27}$ A meta-analysis carried out by Xue et al. in 2013 describes 9 studies conducted in the years 1995-2011. What follows is that ff genotype of the FokI polymorphism in VDR gene is associated with a significant risk of UC in Asians, while the TaqI polymorphism (tt genotype) was associated with an increased risk of CD in Europeans as well as in Asians. ${ }^{18}$ In turn, Wang et al. did not report any correlation between ApaI, BsmI and FokI polymorphisms and IBD. Wang et al. paid particular attention to differences in the genetic profiles of studied patients regarding ethnic differences between them. They have demonstrated no significant differences in the distribution of allele frequencies between the examined groups of IBD and controls, either any relationship between $V D R$ polymorphisms or the occurrence of the disease. ${ }^{20}$ In turn, other studies carried out in the European populations (UK, Germany) revealed the association of the TaqI polymorphism tt genotype with the occurrence of IBD. The authors found that tt genotype was more frequent in patients with $C D$ with numerous fistulas and stenoses. ${ }^{28}$ Interestingly, the latest meta-analysis conducted by Zhang et al. involved 17 studies on patients with postmenopausal osteoporosis and showed no significant relationship between $V D R$ TaqI polymorphism and osteoporosis susceptibility in Caucasians and the overall populations as well. ${ }^{29}$ An earlier report by Sikorska et al. is in concordance with Zhang's findings, although the Polish scientists pointed out the relation of $V D R$ alteration with osteoporotic fractures susceptibility. ${ }^{24}$ Another paper concerning Polish patients with UC has shown no differences in the distribution of VDR TaqI polymorphism in comparison to healthy control subjects. ${ }^{30}$

In our study, we observed the protective effect of the $V D R$ gene TaqI $t$ (c.1057T) allele on BMD in IBD patients and controls. Particularly, UC patients with tt genotypes had a significantly higher FN bone mass. Our observations are contrary to those reported by Morrison et al., who showed that $\mathrm{tt}$ homozygotes had a lower bone mass. ${ }^{25}$ In the study by Noble et al., no association between TaqI VDR polymorphisms and bone mass was shown, and the only independent factor associated with osteoporosis was low BMI. ${ }^{28}$ In our study, we did not show significant differences 
Table 3. Analysis of the Taql polymorphism genotypes with respect to BMD, T-score, Z-score, and 25(OH)D concentration in the study groups

\begin{tabular}{|c|c|c|c|c|}
\hline \multirow{2}{*}{$\begin{array}{l}\text { Parameter } \\
\text { mean (SD) }\end{array}$} & \multicolumn{4}{|c|}{ Crohn's disease } \\
\hline & $\begin{array}{c}\text { TT } \\
n=28\end{array}$ & $\begin{array}{c}\mathrm{Tt} \\
\mathrm{n}=43\end{array}$ & $\begin{array}{c}\mathrm{tt} \\
\mathrm{n}=14\end{array}$ & $p$-value \\
\hline L2-L4 BMD [g/cm²] & $1.11(0.19)$ & $1.12(0.18)$ & $1.15(0.19)$ & $p=0.98$ \\
\hline L2-L4 T-score & $-0.87(1.45)$ & $-0.85(1.44)$ & $-0.61(1.61)$ & $p=0.97$ \\
\hline L2-L4 Z-score & $-0.44(1.41)$ & $-0.44(1.26)$ & $-0.23(1.40)$ & $p=0.90$ \\
\hline FN BMD $\left[\mathrm{g} / \mathrm{cm}^{2}\right]$ & $0.94(0.15)$ & $0.95(0.19)$ & $0.96(0.19)$ & $p=0.99$ \\
\hline FN T-score & $-0.71(1.00)$ & $-0.66(1.36)$ & $-0.52(1.58)$ & $p=0.98$ \\
\hline FN Z-score & $-0.30(0.82)$ & $-0.28(1.14)$ & $-0.17(1.41)$ & $p=0.92$ \\
\hline $25 \mathrm{OHD}[\mathrm{ng} / \mathrm{mL}]$ & $20.04(12.44)$ & $21.95(11.47)$ & $22.62 \pm 15.07$ & $p=0.62$ \\
\hline \multirow[b]{2}{*}{ Parameter } & \multicolumn{4}{|c|}{ Ulcerative colitis } \\
\hline & $\begin{array}{c}\text { TT } \\
n=31\end{array}$ & $\begin{array}{c}\mathrm{Tt} \\
\mathrm{n}=36\end{array}$ & $\begin{array}{c}\mathrm{tt} \\
\mathrm{n}=20\end{array}$ & $p$-value \\
\hline $\mathrm{L} 2-\mathrm{L} 4 \mathrm{BMD}\left[\mathrm{g} / \mathrm{cm}^{2}\right]$ & $1.15(0.12)$ & $1.15(0.16)$ & $1.21(0.13)$ & $p=0.14$ \\
\hline L2-L4T-score & $-0.55(1.09)$ & $-0.52(1.36)$ & $-0.23(0.78)$ & $p=0.41$ \\
\hline L2-L4 Z-score & $-0.21(1.26)$ & $-0.24(1.32)$ & $-0.03(0.78)$ & $p=0.71$ \\
\hline FN BMD $\left[\mathrm{g} / \mathrm{cm}^{2}\right]$ & $0.97(0.14)$ & $0.95(0.16)$ & $1.05(0.12)$ & $\begin{array}{c}p=0.02 \\
{[t t] \text { vs }[t t]} \\
p=0.02 \\
{[t t] \text { vs }[t t]} \\
p=0.08 \\
{[t t] \text { vs }[t t]} \\
p=1.00\end{array}$ \\
\hline FN T-score & $-0.36(1.02)$ & $-0.49(1.30)$ & $0.10(0.94)$ & $p=0.09$ \\
\hline FN Z-score & $0.01(0.99)$ & $-0.06(1.15)$ & $0.37(0.86)$ & $p=0.18$ \\
\hline $25 \mathrm{OHD}[\mathrm{ng} / \mathrm{mL}]$ & $23.60(10.48)$ & $20.97(8.77)$ & $21.63(8.22)$ & $p=0.84$ \\
\hline \multirow[b]{2}{*}{ Parameter } & \multicolumn{4}{|c|}{ Controls } \\
\hline & $\begin{array}{c}\text { TT } \\
n=13\end{array}$ & $\begin{array}{c}\mathrm{Tt} \\
\mathrm{n}=23\end{array}$ & $\begin{array}{c}\mathrm{tt} \\
\mathrm{n}=3\end{array}$ & $p$-value \\
\hline L2-L4 BMD $\left[\mathrm{g} / \mathrm{cm}^{2}\right]$ & $1.25(0.09)$ & $1.20(0.07)$ & $1.31(0.04)$ & $\begin{array}{c}p=0.03 \\
{[t t] \text { vs }[t t]} \\
p=0.08 \\
{[t t] \text { vs }[t t]} \\
p=0.75 \\
{[t t] \text { vs }[t t]} \\
p=0.21\end{array}$ \\
\hline L2-L4T score & $0.32(0.66)$ & $-0.13(0.68)$ & $0.80(0.30)$ & $\begin{array}{c}p=0.03 \\
{[t t] \text { vs }[t t]} \\
p=0.07 \\
{[t t] \text { vs }[t t]} \\
p=0.81 \\
{[t t] \text { vs }[t t]} \\
p=0.15\end{array}$ \\
\hline L2-L4 Z score & $0.34(0.51)$ & $-0.11(0.70)$ & $0.54(0.52)$ & $\begin{array}{c}p=0.03 \\
{[t t] \vee s[t t]} \\
p=0.19 \\
{[t t] \text { vs }[t t]} \\
p=1.00 \\
{[t t] \text { vs }[t t]} \\
p=0.06\end{array}$ \\
\hline FN BMD $\left[\mathrm{g} / \mathrm{cm}^{2}\right]$ & $1.04(0.12)$ & $1.10(0.18)$ & $1.03(0.14)$ & $p=0.58$ \\
\hline FN T score & $0.28(0.76)$ & $0.53(1.19)$ & $0.12(0.81)$ & $p=0.77$ \\
\hline FN Z score & $0.31(0.66)$ & $0.46(1.18)$ & $0.10(0.62)$ & $p=0.93$ \\
\hline 25 OHD [ng/mL] & $21.44(7.11)$ & $22.04(10.65)$ & $18.34(2.86)$ & $p=0.77$ \\
\hline
\end{tabular}

All results are presented as means with standard deviations (SD); BMD - bone mineral density; FN - femoral neck; ns - non-significant; SD - standard deviation. 
in serum vitamin D concentrations between individuals carrying different polymorphic variants; moreover, our IBD patients did not presented any differences in serum $25(\mathrm{OH}) \mathrm{D}$ in comparison to controls. However, in the study conducted on a group of 308 patients with CD in New Zealand, a country with one of the highest incidence rates for this disease in the world, lower vitamin D concentrations were found in IBD patients compared to healthy individuals. These authors correlated low concentrations of $25(\mathrm{OH})$ D with age and low exposure to sunlight. ${ }^{31}$

Polymorphism analyzed in our study has been frequently studied with regard to its contribution to the development of osteoporosis in populations all over the world. The results remained equivocal or even contradictory. Molecular diagnostics based on analyzing allelic variants of candidate genes potentially associated with altered bone turnover in IBD patients would allow us to estimate the predisposition to developing osteoporosis long before the first symptoms appear. This would make it possible to apply prophylaxis or therapies, thus delaying osteoporosis development, which would considerably improve the quality of IBD patients' lives and reduce the cost of healthcare.

\section{Conclusions}

In conclusion, the $V D R$ gene TaqI polymorphism may be related to $\mathrm{BMD}$. We suggest that $\mathrm{tt}$ genotype has a protective effect on BMD particularly in UC patients.

\section{References}

1. Shikhare G, Kugathasan S. Inflammatory bowel disease in children: Current trends. J Gastroenterol. 2010;45(7):673-682.

2. Noomen CG, Hommes DW, Fidder HH. Update on genetics in inflammatory diseases. Best Pract Res Clin Gastroenterol. 2009;23(2):233-243.

3. Franke A, McGovern DP, Barrett JC, et al. Genome-wide meta-analysis increases to 71 the number of confirmed Crohn's disease susceptibility loci. Nat Genet. 2010;42(12):1118-1125.

4. Larsen S, Bendtzen K, Nielsen OH. Extraintestinal manifestations of inflammatory bowel disease: Epidemiology, diagnosis, and management. Ann Med. 2010;42(2):97-11.

5. Ali T, Lam D, Bronze MS, et al. Osteoporosis in inflammatory bowel disease. Am J Med. 2009;122(7):599-604.

6. Bjarnason I, Macpherson A, Mackintosh C, Buxton-Thomas M, Forgacs I, Moniz C. Reduced bone density in patients with inflammatory bowel disease. Gut. 1997;40(2):228-233.

7. Pollak RD, Karmeli F, Eliakim R, Ackerman Z, Tabb K, Rachmilewitz D. Femoral neck osteopenia and mineral metabolism in inflammatory bowel disease. Am J Gastroenterol. 1998;93(9):1483-1490.

8. Peacock M, Turner CH, Econs MJ, Foroud T. Genetics of osteoporosis. Endocr Rev. 2002;23(3):303-326.

9. Ralston SH, Uitterlinden AG. Genetics of osteoporosis. Endocr Rev. 2010;31:(5)629-662.

10. Qin L, Liu Y, Wang Y, et al. Computational characterization of osteoporosis associated SNPs and genes identified by genome-wide association studies. PLOS ONE. 2016;11(3):e0150070.
11. Loddo I, Romano C. Inflammatory bowel disease: Genetics, epigenetics, and pathogenesis. Front Immunol. 2015;6:551.

12. Pike JW, Meyer MB. The vitamin D receptor: New paradigms for the regulation of gene expression by 1,25-dihydroxyvitamin $\mathrm{D}_{3}$. Endocrinol Metab Clin North Am. 2010;39(2):255-269.

13. Palmer MT, Weaver CT. Linking vitamin D deficiency to inflammatory bowel disease. Inflamm Bowel Dis. 2013;19(10):2245-2256.

14. Holick MF. Sunlight and vitamin D for bone health and prevention of autoimmune diseases, cancers and cardiovascular disease. Am J Clin Nutr. 2004;80(6 Suppl):1678S-1688S.

15. McCarthy D, Duggan P, O'Brien M, et al. Seasonality of vitamin D status and bone turnover in patients with Crohn's disease. Aliment Pharmacol Ther. 2005;21(9):1073-1083.

16. Vogelsang H, Schöfl R, Tillinger W, Ferenci P, Gangl A. 25-hydroxyvitamin $D$ absorption in patients with Crohn's disease and with pancreatic insufficiency. Wien Klin Wochenschr. 1997;109(17):678-682.

17. Clements MR, Chalmers TM, Fraser DR. Enteropatic circulation of vitamin D: A reappraisal of the hypothesis. Lancet. 1984;1(8391):1376-1379.

18. Xue LN, Xu KQ, Zhang W, Wang Q, Wu J, Wang XY. Associations between vitamin $D$ receptor polymorphisms and susceptibility to ulcerative colitis and Crohn's disease: A metaanalysis. Inflamm Bowel Dis. 2013; 19(1):54-60.

19. Simmons JD, Mullighan C, Welsh KI, Jewell DP. Vitamin D receptor genepolymorphism: Association with Crohn's disease susceptibility. Gut. 2000;47(2):211-214.

20. Wang L, Wang ZT, Hu JJ, Fan R, Zhou J, Zhong J. Polymorphisms of the vitamin $D$ receptor gene and the risk of inflammatory bowel disease: A meta-analysis. Genet Mol Res. 2014;13(2):2598-2610.

21. Słomski R. Analysis of DNA - theory and practice. Poznan, Poland: Life Sciences Publishing House; 2011.

22. Francis RM, Harrington F, Turner E, Papiha SS, Datta HK. Vitamin D receptor gene polymorphism in men and its effect on bone density and calciumabsorption. Clin Endocrinol (Oxf). 1997;46(1):83-86.

23. Uitterlinden AG, Ralston SH, Brandi ML, et al; APOSS Investigators; EPOS Investigators; EPOLOS Investigators; FAMOS Investigators; LASA Investigators; Rotterdam Study Investigators; GENOMOS Study. The association between common vitamin $D$ receptor gene variations and osteoporosis: A participant-level meta-analysis. Ann Intern Med. 2006;145(4):255-264.

24. Horst-Sikorska W, Dytfeld J, Wawrzyniak A, et al. Vitamin D receptor gene polymorphisms, bone mineral density and fractures in postmenopausal women with osteoporosis. Mol Biol Rep. 2013;40(1): 383-390.

25. Morrison NA, Qi JC, Tokita A, et al. Prediction of bone density from vitamin D receptor alleles. Nature. 1994;367(6460):284-287.

26. Langub MC, Reinhardt TA, Horst RL, Malluche HH, Koszewski NJ. Characterization of vitamin $D$ receptor immunoreactivity in human bone cells. Bone. 2000;27(3):383-387.

27. Langdahal BL, Gravhold CH, Brixen K, Eriksen EF. Polymorphism in the vitamin $\mathrm{D}$ receptor gene and bone mass, bone turnover and osteoporotic fractures. Eur J Clin Invest. 2000;30(7):608-617.

28. Noble CL, Mccullough J, Ho W, et al. Low body mass not vitamin $D$ receptor polymorphisms predict osteoporosis with inflammatory bowel disease. Aliment Pharmacol Ther. 2008;27(7):588-596.

29. Zhang $L, Y$ in $X$, Wang J, et al. Associations between VDR gene polymorphisms and osteoporosis risk and bone mineral density in postmenopausal women: A systematic review and meta-analysis. Sci Rep. 2018;8(1):981.

30. Pluskiewicz W, Zdrzałek J, Karasek D. Spine bone mineral density and VDR polymorphism in subject with ulcerative colitis. J Bone Miner Metab. 2009;27(5):567-573.

31. Carvalho AY, Bishop KS, Han DY, et al. The role of vitamin D level and related single nucleotide polymorphisms in Crohn's disease. Nutrients. 2013;5(10):3898-3909. 